\title{
COMPARATIVE STUDY OF HYSTEROSCOPIC ENDOMETRIAL RESECTION VERSUS THERMACHOICE BALLOON ABLATION IN PERIMENOPAUSAL DYSFUNCTIONAL UTERINE BLEEDING
}

\author{
El-Gharib MN ; *Shawki OA; Balaha MH and Aglaan DM \\ From Departments of Obstetrics \& Gynaecology, Faculty of Medicine, \\ Tanta and * Cairo Universities, Egypt
}

\begin{abstract}
Objectives : To evaluate the effects and sequelae of transcervical resection of the endometrium (TCRE) and thermachoice balloon ablation in the management of perimenopausal dysfunctional uterine bleeding.

Design: Prospective study.

Setting : Tanta and Cairo University Hospitals.

Patients : The study included 70 women complaining of primenopausal dysfunctional uterine bleeding.

Intervention: Women were randomized to either treatment with the endometrial resection or thermal balloon ablation and followed up for 6 months.

Outcome measures: Evaluation of treatment efficacy was done by a scoring system. Quantification of the quality of life aspects was done via a special questionnaire.

Results: The present study revealed that hysteroscopic resection of the endometrium takes an average lime of $34.2 \pm 10.52$ minutes. Regarding the operative and postoperative complications, one patient had perforation, another case developed postoperative hematometra and a third case had persistent excessive bleeding. Blood haemoglobin and serum ferritin increased significantly within 6 months after the operation. The operation resulted in a reduction in bleeding score at 3, 6 nd 12 months respectively. About $81 \%$ of women felt very satisfied and satisfied within one year. Thermachoice balloon ablation takes an average of $12.4 \pm 4.32$ minutes. Operative and postoperative complications, pregnancy occurred in one case 3 months after the procedure. Blood haemoglobin and scrum ferritin increased significantly wihin 6 months after the procedure. The procedure reduced bleeding score at 3, 6 and 12 months respectively. Whithin one year after the procedure, $80 \%$ of patients felt very satisfied and and satisfied were $80 \%$.

Conclusion: Hysteroscopic endometrial ablation and thermachoice balloon ablation are both effective in women with dysfunctional uterine bleeding especially in patients who complete their families and desire to retain their uteri.

Key words: Hysteroscopy, endometrial resection, thermachoice balloon ablation and dysfunctional uterine bleeding.
\end{abstract}

\section{INTRODUCTION}

Menorrhagia is a common gynecologic complaint and frequently needs a surgical treatment ${ }^{(1)}$. It is the most common cause of iron deficiency anemia in healthy fertile women ${ }^{(2)}$.

Hysterectomy is the most common surgical procedure used in those cases that are unresponsive to medical treatment despite the diffusion of minimal access hysteroscopic procedures as alternatives ${ }^{(3)}$. It has been reported to be more effective in releiving menstrual symptoms and has a higher patient satisfaction rate but is significantly more invasive ${ }^{(4)}$.

Endometrial ablation with electrosurgery, laser or other forms of thermal energy has been introduced as a less invasive alternative to hysterectom ${ }^{(5)}$. Hysteroscopic surgery is associated with a shorter operating time, fewer operative complications, lower analgesic requirements, faster return to normal activity and large financial savings $(6,7$ and 8$)$. However, 
hysteroscopic ablation requires additional specialized training and surgical expertise. Moreover, serious complications may occur, including fluid overload, uterine perforation, infection, hacmorrhage, thermal injuries, and even death. In the Mistlestoe study, 10,686 women were treated with endometrial ablation performed by 690 different surgeons and by different methods; the complication rate was $4.4 \%(9)$.

In the interests of overcoming many of these disadvantages and risks, a thermal uterine balloon therapy system was developed that has been evaluated in several clinical studies of endometrial destruction (10-12). Many clinical studies were done to elucidate the role of thermal balloon in the amelioration of dysfunctional uterine bleeding (13-16).

The aim of this study was to evaluate the effects and sequelae of hysteroscopic endometrial resection and thermachoice balloon ablation in the management of perimenopausal dysfunction uterine bleeding.

\section{PATIENTS}

The present study was conducted at the Gynecological Department at both Tanta University Hospitals and Cairo University Hospitals, during the period from july 2003 through February 2006. All eligible women presenting with menorrhagia, which was diagnosed as dysfunctional uterine bleeding and met the inclusion criteria, were counseled to be enrolled in the study. Seventy patients who accepted were recruited and randomized into 2 groups according to the given method of treatment.

- Group I: Included 35 patients where transcervical resection of the endometrium (TCRE) was performed.

- Group II: Included 35 patients where ablation of the endometrium was performed by thermachoice balloon.

\section{Inclusion criteria :}

- Patients at the perimenopausal age (40-50 years).

- Dysfunctional uterine bleeding with no organic pelvic pathology.

- Failure of medical treatment for at least 6 months.

- Failure of $\geq$ one dilatation and curettage operation.

- Uterine size $\leq 12$ weeks size and the uterine cavity $\leq$ $12 \mathrm{~cm}$ measured from fundus to external cervical opening.

- All patients completed their family and wish to retain their uterus.

\section{Exclusion criteria :}

- Patients desiring amenorrhea as an end resutl of treatment.

- Uterine size $\geq 12$ weeks size and the uterine cavity $\geq$ $12 \mathrm{~cm}$.

- Congenital or acquired uterine malformations that distort the uterine cavity.

- Cases with endometrial polypi or fibroid uterus.

- Malignancy or atypia of endometrium as proved by recent histopathology of curettage specimens.

- Cases of adenomatous hyperplasia, despite they were not a contraindication, they were not included.

- Cases of coagulopathy known by history or investigations and Cases with $\mathrm{FSH} \geq 30 \mathrm{mIU} / \mathrm{ml}$.

- Incidental adnexal abnormality, uninvestigated postcoital bleeding and untreated abnormal cervical cytology.

- Severe dysmenorrhoea, severe premenstrual pain and chronic pelvic pain.

- Fixed retroverted uterus or the presenc eof pelvic tenderness.

- The presence of uterine scars (previous Cesarean section, myomectomy etc.).

- Medical contraindications to either treatment or history of previous endometrial ablation or resection.

\section{METHODS}

Women were randomized to either treatment with the endometrial resection or thermal balloon ablation and followed up for 3, 6 and 12 months. All patients in both groups were subjected to: 
- History taking, clinical and bimanual examination.

- Investigations: Routine investigations as chest $\mathrm{x}$ ray and ECG assessment were done to assess operability. Specific investigations including haemoglobin level for anaemia, serum ferritin, bleeding score (17), coagulation profile tests (bleeding time, clotting time and platelets counts), Liver function tests including prothrombin time and renal function tests.

- Ultrasonographic imaging to exclude large uterine or adnexal masses that may be missed by transvaginal examination.

- Diagnostic hysteroscopic examination and recent endometrial sampling was previously done in all patients in both groups.

- Operative procedure:

- Group I: Hysteroscopic transcervical resection of the endometrium.

- Group II: Therma Choice Balloon therapy system ablation.

- Evaluation of treatment efficacy was done by Magos $\operatorname{method}^{(18)}$.

- To quantify the quality of life aspects we used the questionnaire developed and validated by Ruta et al (19).

- Patient satisfaction was also assessed using a $10-\mathrm{cm}$ VAS labeled as follows: not satisfied $(03.5 \mathrm{~cm})$; satisfied (4 $7.5 \mathrm{~cm})$; and very satisfied $(810 \mathrm{~cm})$. The VAS score was obtained by measuring the distance marked on the VAS but rounded to the nearest $0.5 \mathrm{~cm}$. The use of a categorical outcome rather than the raw numerical data from the visual analogue scores was used in the analysis as we consider it easier to interpret in terms of the clinical conditions, whereas the numbers may be difficult 10 translate easily to a clinical outcome. Although not validated, the clinical outcomes are directly related to the underlying score. VAS assessments were done pre-operatively and assessed at the follow up visits.

\section{RESULTS}

The age of both groups, in group I ranged from 40-49 years (with a mean of 43.22 44.5 ), that of group II ranged from 40-50 years (with a mean of 43.28 3 3.99). There was no statistically significant difference in the age of both groups. There was no statistically significant difference in parity of both groups.

Clinical examination revealed that there were 10 obese patients in each group. There was a hypertensive and diabetic case in each group. Group II included a cardiac patient.

Histopathological study of the endometrium revealed that endometrial hyperplasia was the commonest endometrial pattern in both groups, constituting $57 \%$ in group I and $60 \%$ in group II. There was no statistically significant difference in the histopathology of both groups.

Table I : Endometrial histopathology in both groups.

\begin{tabular}{|l|c|c|c|c|c|c|}
\hline \multirow{2}{*}{} & \multicolumn{2}{|c|}{ Group I } & \multicolumn{2}{c|}{ Group II } & \multicolumn{2}{c|}{ Total } \\
\cline { 2 - 8 } & $\mathrm{N}$ & $\%$ & $\mathrm{~N}$ & $\%$ & N & $\%$ \\
\hline Simple hyperplasia & 20 & 57.14 & 21 & 60.00 & 41 & 58.57 \\
\hline Proliferative & 10 & 28.57 & 9 & 25.71 & 19 & 27.14 \\
\hline Secretory & 5 & 14.29 & 5 & 14.29 & 10 & 14.29 \\
\hline Total & 35 & 100.00 & 35 & 100.00 & 70 & 100.00 \\
\hline \multirow{2}{*}{ Chi-square } & $\chi^{2}$ & P-value & \multicolumn{7}{|c|}{0.077} \\
\cline { 2 - 7 } & & \multicolumn{7}{|c|}{0.962} \\
\hline
\end{tabular}


- In Group I: The mean duration of menses was $8 \pm 2.34$ day, mean blood hemoglobin level was $9.8 \pm 2.32 \mathrm{gm} / \mathrm{dl}$, mean serum ferritin was $11.1 \pm 3.2$ ug/dl and mean uterine length was $10.2 \pm 2.6 \mathrm{~cm}$. The mean duration of cervical dilatation and rescction of the endometrium (time of anaesthesia was not included) was $34.2 \pm 10.52$ minutes with a range of 15-45 minutes.

- In Group II: The mean duration of menses was $8.5 \pm 1.95$ day, mean hemoglobin level was 9.5-1.95 gm/dl, mean serum ferritin was $11.9 \pm 4.54 \mathrm{ug} / \mathrm{L}$ and mean uterine length was $10.6 \pm 2.23 \mathrm{~cm}$. The mean duration of cervical dilatation and resection of the endometrium (time of anaesthesia was not included) was 12.444 .32 minutes with a range of $15-45$ minutes.

- In group 1, 6 months after the operation, blood hemoglobin and serum ferritin were $10.3+2.35$ $\mathrm{gm} / \mathrm{dl}, 23.65 \mu \mathrm{g} / \mathrm{l}$ from a base line of $9.8 \pm 1.23 \mathrm{gm}$ and $11.1 \pm 2.34 \mu \mathrm{g} / 1$. In group II, blood haemoglobin and serum ferritin were $10.8+1.95 \mathrm{mg} / \mathrm{dl}$ and $22.5 \pm 4.53 \mu \mathrm{g} / \mathrm{l}$ from a base line of $9.50 \pm 1.46 \mathrm{mg} / \mathrm{dl}$ and $11.9 \pm 2.11 \mu \mathrm{g} /$. There was a significant improvement in the hematological profile of both groups.

Table II : Serum ferritin before and 6 months after the operation.

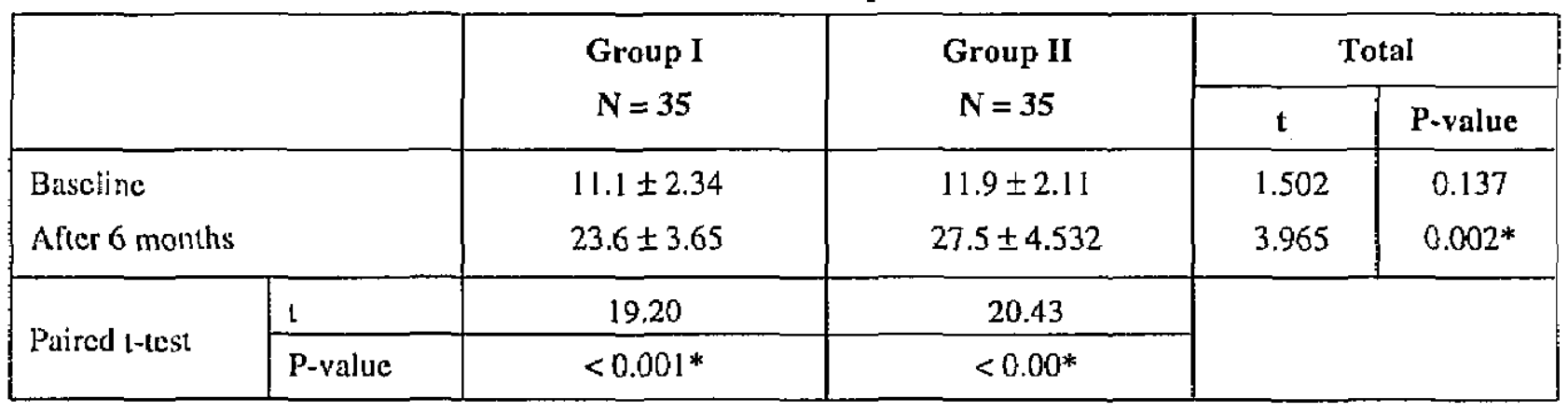

Table III : Operative and postoperative comptications.

\begin{tabular}{|l|c|c|c|c|c|c|}
\hline \multirow{2}{*}{} & \multicolumn{2}{|c|}{ Group I N = 35 } & \multicolumn{2}{c|}{ Group II N=35 } & \multicolumn{2}{c|}{ Total N=70 } \\
\cline { 2 - 7 } & $\mathbf{t}$ & $\mathbf{P}$-value & $\mathbf{t}$ & P-value & $\mathbf{t}$ & P-value \\
\hline Perforation & 1 & 2.9 & 0 & 0.00 & 0 & 0.00 \\
\hline Pregnancy & 0 & 0.00 & 1 & 2.86 & 1 & 1.43 \\
\hline Haematomctra & 1 & 2.86 & 0 & 0.00 & 1 & 1.43 \\
Blceding & $\mathrm{I}$ & 2.86 & 0 & 0.00 & 1 & 1.43 \\
No complication & 32 & 91.4 & 34 & 94.4 & 66 & 94.3 \\
\hline
\end{tabular}




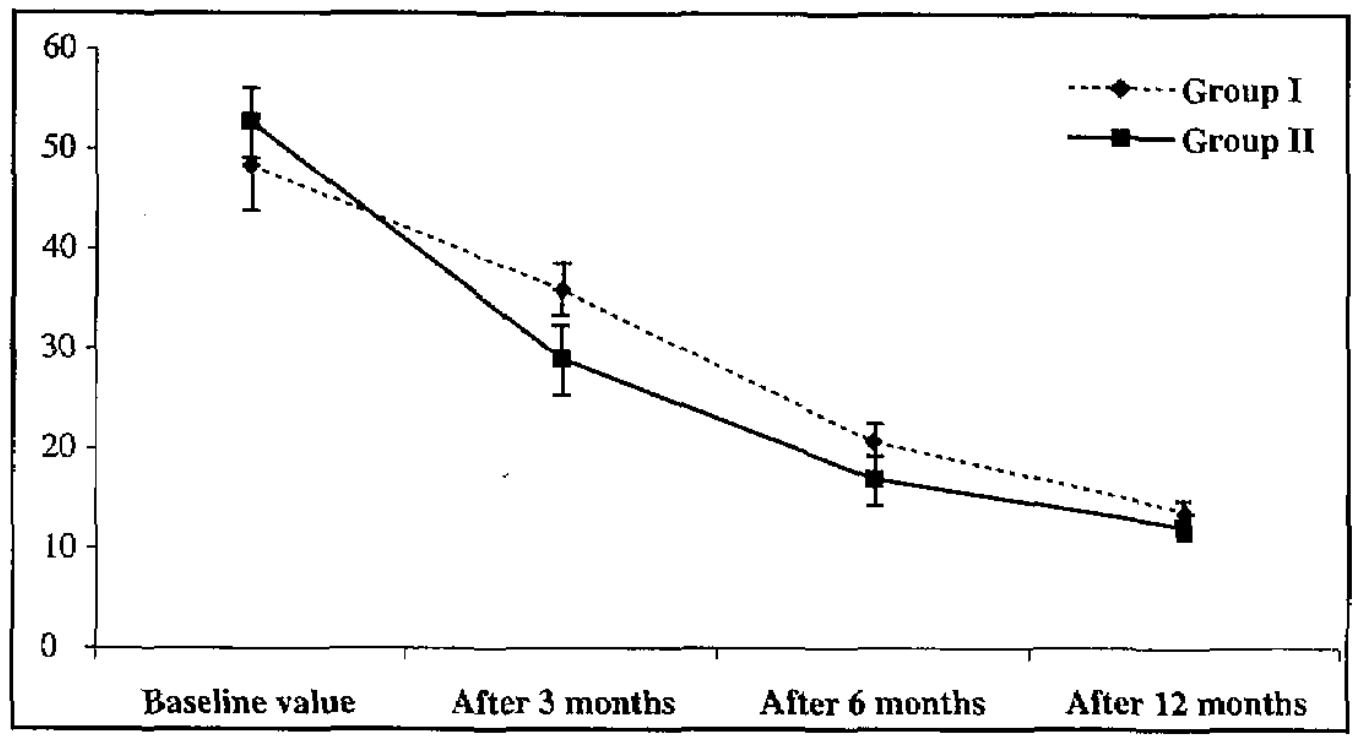

Fig. 1. Bleeding score afte 3,6 and 12 months.

Table IV : The effect of ablation and Thermachoice balloon on menstrual pattern after 3, 6 and 12 months.

\begin{tabular}{|c|c|c|c|c|c|c|c|}
\hline \multirow{2}{*}{$\begin{array}{c}\text { Menstrual } \\
\text { pattern }\end{array}$} & & \multicolumn{2}{|c|}{ After 3 months } & \multicolumn{2}{|c|}{ After 6 months } & \multicolumn{2}{|c|}{ After 12 months } \\
\hline & & $\begin{array}{c}\text { Group I } \\
\mathbf{N}=\mathbf{3 5}\end{array}$ & $\begin{array}{c}\text { Group II } \\
N=35\end{array}$ & $\begin{array}{c}\text { Group I } \\
\mathbf{N}=\mathbf{3 5}\end{array}$ & $\begin{array}{c}\text { Group II } \\
N=35\end{array}$ & $\begin{array}{c}\text { Group I } \\
\mathbf{N}=\mathbf{3 1}\end{array}$ & $\begin{array}{c}\text { Group II } \\
N=30\end{array}$ \\
\hline \multirow{2}{*}{ Amenorrhea } & $\mathrm{N}$ & 10 & 7 & 14 & 10 & 15 & 13 \\
\hline & $\%$ & 28.57 & 20.00 & 40 & 28.57 & 48.39 & 43.33 \\
\hline \multirow{2}{*}{ Hypomenorrhea } & $\mathrm{N}$ & 2 & 3 & 5 & 8 & 5 & 7 \\
\hline & $\%$ & 5.71 & 8.57 & 14.28 & 22.86 & 16.13 & 23.33 \\
\hline \multirow{2}{*}{ Eumenorrhea } & $\mathrm{N}$ & 4 & 8 & 7 & 7 & 5 & 4 \\
\hline & $\%$ & 11.43 & 22.86 & 20.00 & 20.00 & 16.13 & 13.33 \\
\hline \multirow{2}{*}{ Menorthagia } & $\mathrm{N}$ & 17 & 12 & 3 & 6 & 2 & 4 \\
\hline & $\%$ & 48.57 & 34.29 & 8.57 & 17.14 & 6.45 & 13.33 \\
\hline \multirow{2}{*}{ Spotting } & $\mathrm{N}$ & 2 & 5 & 6 & 4 & 4 & 5 \\
\hline & $\%$ & 5.71 & 14.29 & 17.14 & 11.43 & 11.43 & 16.67 \\
\hline \multirow{2}{*}{ Chi-square } & $x^{2}$ & \multicolumn{2}{|c|}{4.211} & \multicolumn{2}{|c|}{4.394} & \multicolumn{2}{|c|}{1.304} \\
\hline & $\mathrm{P}$ & \multicolumn{2}{|c|}{0.378} & \multicolumn{2}{|c|}{0.355} & \multicolumn{2}{|c|}{0.861} \\
\hline
\end{tabular}

Table V : Satisfaction rate after ablation

\begin{tabular}{|l|c|c|c|c|c|c|c|}
\hline \multicolumn{2}{|c|}{} & \multicolumn{2}{c|}{ After 3 months } & \multicolumn{2}{c|}{ After 6 months } & \multicolumn{2}{c|}{ After 12 months } \\
\cline { 2 - 8 } & $\begin{array}{c}\text { Group I } \\
\mathbf{N}=\mathbf{3 5}\end{array}$ & $\begin{array}{c}\text { Group II } \\
\mathbf{N}=\mathbf{3 5}\end{array}$ & $\begin{array}{c}\text { Group I } \\
\mathbf{N}=\mathbf{3 5}\end{array}$ & $\begin{array}{c}\text { Group II } \\
\mathbf{N}=35\end{array}$ & $\begin{array}{c}\text { Group I } \\
\mathbf{N}=\mathbf{3 1}\end{array}$ & $\begin{array}{c}\text { Group II } \\
\mathbf{N}=\mathbf{3 0}\end{array}$ \\
\hline \multirow{2}{*}{ Very satisfied } & $\mathrm{N}$ & 10.00 & 7.00 & 13.00 & 9.00 & 15.00 & 13.00 \\
& $\%$ & 28.57 & 20.00 & 37.14 & 25.71 & 48.39 & $\mathbf{4 3 . 3 3}$ \\
\hline \multirow{2}{*}{ Satisfied } & $\mathrm{N}$ & 6.00 & 11.00 & 8.00 & 16.00 & 10.00 & 11.00 \\
& $\%$ & 17.14 & 31.43 & 22.86 & 45.71 & 32.26 & $\mathbf{3 6 . 6 7}$ \\
\hline \multirow{2}{*}{ Unsure } & $\mathrm{N}$ & 7.00 & 5.00 & 5.00 & 5.00 & 5.00 & $\mathbf{5 . 0 0}$ \\
& $\%$ & 20.00 & 14.29 & 14.29 & 14.29 & 16.13 & $\mathbf{1 6 . 6 7}$ \\
\hline \multirow{2}{*}{ Not satisfied } & $\mathrm{N}$ & 12.00 & 12.00 & 9.00 & 5.00 & 4.00 & 1.00 \\
& $\%$ & 34.29 & 34.29 & 25.71 & 14.29 & 12.90 & 3.33 \\
\hline
\end{tabular}


Table VI : Hysteroscopic findings 6 months after the operation.

\begin{tabular}{|l|c|c|c|c|c|c|}
\hline \multirow{2}{*}{} & \multicolumn{2}{|c|}{ Group I N=35 } & \multicolumn{2}{c|}{ Group II N=35 } & \multicolumn{2}{c|}{ Total N=70 } \\
\cline { 2 - 7 } & $\mathrm{N}$ & $\mathbf{\%}$ & $\mathrm{N}$ & $\%$ & $\mathrm{~N}$ & $\%$ \\
\hline Focal intrauterine adhesions & 13 & 37.14 & 6 & 17.14 & 19 & 27.14 \\
\hline Complete adhesions & 3 & 8.57 & 6 & 17.14 & 9 & 12.86 \\
\hline Fibrotic cavity & 1 & 2.85 & 11 & 31.43 & 12 & 17.14 \\
\hline Normal cavity & 1 & 2.85 & 11 & 31.42 & 12 & 17.14 \\
\hline Tubular cavity & 17 & 48.57 & 1 & 2.85 & 18 & 25.71 \\
\hline Total & 35 & 100.00 & 35 & 100.00 & 70 & 100.00 \\
\hline
\end{tabular}

Table VII : Hysteroscopic findings at second look Hysteroscopy and menstrual pattern.

\begin{tabular}{|l|c|c|c|c|c|c|c|c|c|c|}
\hline & \multicolumn{2}{|c|}{$\begin{array}{c}\text { Focal } \\
\text { intrauterine } \\
\text { adhesions }\end{array}$} & \multicolumn{2}{|c|}{$\begin{array}{c}\text { Complete } \\
\text { adhesions }\end{array}$} & \multicolumn{2}{c|}{$\begin{array}{c}\text { Fibrotic } \\
\text { cavity }\end{array}$} & \multicolumn{2}{c|}{$\begin{array}{c}\text { Normal } \\
\text { cavity }\end{array}$} & \multicolumn{2}{c|}{$\begin{array}{c}\text { Tubular } \\
\text { cavity }\end{array}$} \\
\hline Amenorrhea & 1 & 1 & 1 & 6 & 1 & 2 & 0 & 0 & 11 & 1 \\
\hline Spotting & 4 & 2 & 2 & 0 & 0 & 2 & 0 & 0 & 0 & 0 \\
\hline Hypomenorrhea & 2 & 1 & 0 & 0 & 0 & 7 & 0 & 0 & 3 & 0 \\
\hline Eumenorrhca & 3 & 1 & 0 & 0 & 0 & 0 & 1 & 6 & 3 & 0 \\
\hline Menorrhagia & 3 & 1 & 0 & 0 & 0 & 0 & 0 & 5 & 0 & 0 \\
\hline Total & 13 & 6 & 3 & 6 & 1 & 11 & 1 & 11 & 17 & 1 \\
\hline
\end{tabular}

\section{DISCUSSION}

Menorrhagia is defined as measured menstrual blood loss of $80 \mathrm{ml}$ or more per cycle. This is known as objective menorrhagia and is accepted as the "gold standard" definition (3).

Aproximately $20-25 \%$ of healthy premenopausal women have abnormal uterine blecding. The prevalence of abnormal uterine bleeding increases with age, peaking at about the fifth decade of life. In The United States, approximately 600,000 hysterectomies are performed annually and it is estimated that $20 \%$ to $25 \%$ of them are due to excessive menstrual bleeding unresolved by medical management ${ }^{(20)}$.

Endometrial ablation was introduced in the 1980's as an alternative for hysterectomy in patients with abnormal uterine bleeding (21). These methods vary from thermal ablative techniques by hot water directly or in a balloon lying in the uterine cavity, to clectrocoagulation, microwave or laser emission (22). Thermachoice received Food and Drug Administration approval $^{(22)}$.

In the present study 70 patients complaining of dysfunctional uterine bleeding were recruited from the outpatient clinic and were randomly assigned to one of either groups; group I subjected to hysteroscopic resection of the endometrium and group II that was subjected to thermachoice balloon ablation. The cases were follwed up at 3,6 and 12 months, where operative time, complications, menstrual pattern, bleeding score and satisfaction rate were compared. At th $\theta^{\text {h }}$ month visit, hemoglobin, serum ferritin were reevaluated and 2nd look hysteroscopy were done to evaluate the uterine cavity and correlate it with menstrual pattern. 
As regards to operative and postoperative complications of hysteroscopic resection of the endometrium, we found that the mean duration of the operation was $34.2+10.52$ minutes. Uterine perforation and excessive bleeding each occurred in $2.86 \%$ of our cases. Postoperative hematometra was found in one patient $(2.86 \%)$. These resutls agree with that of many other investigators $(16,9)$.

The current study supported the results of many authors $(8,24,25)$, that TCRE enhanced postoperatively all the hematological parameters of the patients within 6 months.

As regard to satisfaction rate, patients who felt very satisfied and satisfied were $80.65 \%$ within 12 months. At the same time, $16.13 \%$ of patients felt unsure and $12.9 \%$ felt unsatisfied.

Considering 2nd look hysteroscopy, we found that 13 women (37.14\%) had focal intrauterine adhesions, one of them had amenorrhea, four had spotting, two had hypomenorthea, three had eumenorrhea and three had menorrhagia. Three women had complete adhesions one of them amenorrhea and the remaining two had spotting. One case had fibrotic cavity and presented by amenorrhea and another one had normal cavity and presented by eumenorrhea. Tubular cavity was found in 17 cases $(48.57 \%), 11$ of them had amenorrhea, 3 had spotting and the remainign 3 were eumenorrheic.

Istre an coworkers performed second-look hysteroscopy in 58 women one year afte transcervical resection of endometrium and reported that the uterine cavity generally appeared as a narrow tube. They concluded that this was the result of the fibrosis or occlusion of the peripheral part of the uterine cavity. Focal adhesions were observed in $40 \%$ of patients, but no patient developed total obliteration of the cavity ${ }^{(26)}$.

The resutls of Thermachoice balloon ablation in the present study revealed that it takes an average of 12.4 \pm 4.32 minutes. As regard operative and postoperative complications, pregnancy occurred in (2.85\%) one out of 35 cases after 3 months of the procedure. These results are consistent with the conclusions of many authors $(23,11,28,29)$.

Istre and coworkers reported that post-operative complication rates in both groups were low, but post operative analgesiscs were prescribed significantly more in the uterine balloon group and more cases returned to the hospital for analgesia (26).

Solnik et al studied the rate of thermachoice balloon ablation and incidence of admission after the procedure and they found that thermachoice balloon constitutes $72.1 \%$ of the procedures and hysteroscopic ablation $27 \%$ and they attributed this to the casiness and efficacy of the balloon; also they found more postoperative admission after thermachoicc balloon as it was $13.7 \%$ versus $3.1 \%$ for hystcroscopic ablation and cause of readmission was due to pain and they attributed this to little usage of analgesia postoperatively and they recommended prescription of postoperative analgesics (31). This was not the case in our study, as we kept women for 24 hours in the ward after the operation to safeguard against any post operative condition.

Ulmsten and others stated that the success rate in terms of a $50 \%$ reduction in menstrual bleeding was $84.3 \%$ at 6 months after treatment. Five patients became amenorrhoeic ${ }^{(28)}$.

Ola'h and coworkers assessed the fescibility of performing outpatient thermal ablation in a primary care setting. Eighly-seven women were treated. No major complications were encountered from the procedure. Reduction of menstrual loss or cure was reported by over $94 \%$ of women. Premenstrual syndrome and symptoms of dysmenorrhoea were also improved by treatment ${ }^{(2)}$.

As regard to satisfaction rate, patients who felt very satisfied and satisfjed were $80 \%$ within 12 months. At the same time, $16.67 \%$ of patients felt unsure and $3.33 \%$ felt unsatisfied. 
Ulmsten and coworkers stated that the quality of life assessment after thermal balloon endometrial ablation showed substantial improvement and the severily of dysmenorrhoea was markedly reduced ${ }^{(28)}$. Ola'h ct al used thermal balloon endometrial ablation and reported that the majorty of women were satisfied with the operation at one month (96\%) two months $(93 \%)$, one year $(92 \%)$ and $94 \%$ after two years ${ }^{(28)}$. These results are very close 10 and consistent with the results of the present study.

As regard to 2nd look hysteroscopy and its correlation with menstrual pattern $17.14 \%$ had focal intrauterine adhesions, one of them had amenorrhea, 2 had spolting and one had hypomenorrhea, sne had cumenorrhea and the last case had menorrhagia. $17.14 \%$ (6/35) had complete adhesions all of them amenorrhoeic $31.43 \%(11 / 35)$ had fibrotic cavily 2 of them amenorrhocic, 2 had spolting and the remaining 7 had hypomenorrhea, $31.4 \%$ (11/35) had norml cavity 6 of them eumenorrhea and the remaining 5 had menorthagia.

Buckshee el al. reported that hysteroscopic findings in six paticnts at 6 months after the procedurc. They reported that "more than two thirds of the endometrium appeared scarred"; however, it is not clear whether ":two thirds" refers to each uterine cavily or the proportion of total patients. The authors also staled that both ostia were visualized in all patients except one amenorthocic patient, whose endometrial cavity appeared cotally scarred with bilateral stenotic ostia. They did not evaluate a possible correlation between the hysteroscopic finding and the menstrual outcome ${ }^{(33)}$.

Pui et al lound that postablation intrauterine adhesions vary considerably. They were found in eight women (36.4\%); six had focal adhesions in the fundal area and two had complete obliteration of the cavity. Of these eight women, three had spotting during menstruation, three had hypomenorrhea, one had eumenorrhea, and one had amenorrhea. The uterine cavity was fibrotic in four (18\%) women; all reported spotting during menstruation. Ten women had a normal uterine cavily; eight had hypomenorrhea, one had spotting, and one had eumenorthea ${ }^{(34)}$.

The findings in the previous two studies support a correlation between menstrual outcome and the post ablation appearance of the uterine cavity. All women with fibrotic uterine cavity had minimal menstrual blood loss, whereas women with focal adhesions and normal cavity had this menstrual outcome.

Morgan and Advincula had concluded that the evolution of endometrial ablation to its second generation devices had allowed gynecologists to continue to manage menorrhagia in a minimlly invasive fashion. An cfficacy that paralleis traditional hysteroscopic ablative techniques had been of paramount importance while also improving the safety profiles and ease of use of these devies. As a resul] of these changes, there has also been a trend towards the periormance of these procedures in an office setting ${ }^{(35)}$.

Mcyer $\mathrm{ct}$ al stated that intraoperative complications occurred in $3.2 \%$ of the RB patients, whereas no intraoperative complications occurred in the UBT group. Despite these findings, $85.6 \%$ of the UBT patients and $86.7 \%$ of the Roller ball patients were highly satisfied with their results ${ }^{(36)}$.

The results of the present study agree with the results of Gervaise, et al who studied thermal balloon ablation versus endometrial resection for the treatment of abnormal uterine bleeding and they found that the overall success rate was $83.0 \pm 5 \%$ and $76.3 \pm 6 \%$ in both groups respectively; with no significant difference ${ }^{(37)}$.

The results of the present study point to the same direction as previous results. It is to be noted that, we used the resectoscope instead of roller ball. It was found that the overal success rate did not differ significantly between the two methods of ablation.

Van Zon-Rabelink and associates studied endometrial ablation by rollerball electrocoagulation compared to uterine balloon thermal ablation and they 
found that rollerball electrocoagulation carries a significantly higher risk of intra-operrative complications compared to uterine balloon thermal ablation and is a significantly more time consuming procedure. they found that reduction of menstrual blood loss was significantly more successful at 24 months for thermal ablation with uterine balloon ${ }^{(30)}$. These results agree with the results of our current study.

Lastly, we conclude that hysteroscopic endometrial ablation and thermachoice balloon ablation are both effective in women with dysfunctional uterine bleeding especially in patients who completed their families and desire to retain their uteri.

\section{REFERENCES}

1. Coulter A, Bradlow J, Agass M, Martin-Bates C, Tulloch A. Outcomes of referrals to gynecology outpatient clinics for menstrual problems: an audit of general practice records. Br J Obstet Gynaecol, 1991; 98: 789-796.

2. Apgar BS: Dysmenorrhoea and dysfunctional uterine bleeding. Primary care. Clinics and Office Practice, 1997; 24: 161-187.

3. Vessey MP, Viilard-Mackintosh I, Mcpherson K, Coulter A, Yeates D. The epidemiology of hysterectomy: Findings in a large cohort study. Br J Obstet Gynaecol. 1992; 99: 402-407.

4. Unger JB and Meeks GR. Hysterectomy after endometrial ablation. Am J Obstet Gynecol. 1996; 175: 1432-1437.

5. Magos AL. Management of menorrhagia. BMJ. 1990; 300: 1537-1538.

6. gannon MJ, Holt EM, Fairbank J. A randomised trial comparing endometrial resection an abdominal hysterectomy for the treatment of menorrhagia. BMJ. 1991; 102: 249-254.

7. Dwyer N, Hutton J, Stirrat GM. Randomized controlled trial comparing endometrial resection with abdominal hysterectomy for surgical treatment of menorrhagia. Br J Obstet Gynecol. 1993; 100 : 237-243.

8. Pinlon SB, Parkin DE, Abramovich DR.
Randomised trial of hysterectomy, endometrial laser ablation, and transcervical endometrial resection for dysfunctional uterine bleeding. BMJ. 1994; 309: 979-983.

9. Overton C, Hargreaves J, Maresh A. A national survery of the complication of endometrial destruction for menstrual disorders. The milestione study Br J Obstet Gynecol. 1997; 104: 1351-1359.

10. Neuwirth RS, Duran AA, Singer A. The endometrial ablator: a new instrucment. Obstet Gynecol. 1994; 83, 792-796.

11. Amso N, Stablinsky S, Mefaul P, Blance B, Pendley $L$ and Neuwirth $R$,. Uterin thermal balloon therapy for the treatment of menorrhagia: The first 3000 patients from a multicentre study. Br. J. Obstet.. Gynecol . 1998; 105, 517-523.

12. Friberg B, Persson BR and Willen R. Endometrial Destruction by Hyperthermia;' A Possible Treatment of Menorrhagia. Acta Obstet. Gynecol. Scand. 1996; $75,330-335$.

13. Decherney AH and Polan ML. Hysteroscopic Management of Intrauterine Lesions and Intractable Iterine Bleeding. Obstet. Gynecol. 1983; 61. 392-396.

14. Garry R, Shelley-Jones D and Mooney P. Sxi Hundred Endometrial Laser Ablations. Obstel. Gynecol. 1995; 85, 24-29.

15. Goldrath $\mathrm{MH}$, Hysteroscopic Endometrial Ablation. Obstet. Gynecol. Clin. N. Amer. 1995; 22, 559-572.

16. O'connor $\mathrm{H}$ and Magos A. Endometrial Resection for the Treatment of Menorrhagia. N. Engl. J. Med. 1996; 335, 1515-156.

17. Serebruany VL and Atar D. Assessment of Bleeding Events in Cllinical Trials-Proposal of A New Classification. Am J Cardiol. 2007; 99: 288-290.

18. Magos AL.; Baumann $R$ and Turnbull AC. Transcervical Resection of the Endometrium In Women with Menorrhagia. Br Med J. 1989; 298: 1209-1212.

19. 141-Phipps JH, Smith $T$ and Levis BV. Measurement of Menstrual Blood Loss By Whole Body Warming: In Magos AL nd Levis BV (Eds.): Endometrial Ablation Churchill Living Stone, 1993; 205.

20. Carlson KJ, Nichols DH and Schiff I. Indications for Hysterectomy. N Engl J Med 328 1993, pp. 856-860.

21. Daniell JF, Kurtz BR and KE RW. Hysteroscopic Endometrial Ablation Using the Roller Ball 
Electrode. Obstet Gynccol. 1992; 80: 329-332.

22. Singer A, Almanac R, Gulierrez A, Huber G, Bolduc LR, Neuwirth R. Preliminary Clinical Expcrience with A thermal Balloon Endometrial Ablation Method To Treat Menorrhagia. Obstet, gynccol. 1994,m 83, 732-734.

23. Sutton C. Hysteroscopic Surgery. Best Practice \& Rescarch Clinical Obstetrics \& Gynaecology 20,1, 2006; $105-137$.

24. Brooks PG. Clouse J. and Stock well ML. Hysterectomy Vs. Resectoscopic Endometrial Ablation for the Control of Abnormal Ulerine Blceding. A cost-Comparative Study. J Reprod Med. 1994; 39: 755-760.

25. Nagele $F$, Rubinger $T$ and Magos $A$. Why Do Womes Choose Endometrial Ablation Rather Than Hysterectomy? Fertil Steril. 1998; 69: 1063-1066.

26. Istre $O$, Skajaa $K$ and Holm-Nielsen $P$, the second-Look Appearance of The Uterine Cavity After Resection of the Endometrium. Gynaccol Endose. 1993; 2: 189-191.

37. Vilos GA, Vilos EC and Pendley L. Endometrial Ablation with $A$ thermal Balloon for the Treatment of Menorthigia. J Am Assoc Gynccol Laparos. 1996; 3: 383-387.

28. Ulmsten U, Carstensen H, Falconer C, Holn L, Lannér L, Nilsson S, rasmussen C, Redvall L, Rídestad A, Simonsen B and Bergelin I. the Safety and Efficacy of Menotreat ${ }^{T M}$. A New Balloon Device For Thermal Endometrial Ablation. Acta Obstet Gynecol Scand. 2001; 80: 52-57.

29. El-loukhy T, Chandakas S, Grigoriadis T, Hill N and Erian J. Outcome of the .1st 220 cases of Endometrial Balloon Ablation Using Cervalermimplus, Joumal of Obstetrics and Gynaccology. 2004; 24(6): 680-683.
30. Van Zon-Rabelink, Ingrid AA, Vleugels, Michel $\mathrm{PH}_{1}$ Merkus, Hans MWW and Graaf. Endometrial Ablation by Rollerball Electrocoagulation Compared to Uicrine Balloon Thermal Ablation. European Journal of Obstetrics \& Gynecology And Reproductive Biology, 110,2, 10, 2003, p 220-223.

31. Solnik JM, Guido RS, Sanfilippo JS, Marijane MBA and Krohb A. The Impact of Endometrial Ablation Technique Al a Large Univesity Women's Hospital. Am J Obstet Gynecol. 2005; 193: 98-102.

32. Karl S, Allision OJ, Joanne B, Julia J, Stewart BG and Mavrommalisc R. Thermal Ablation Performed In a Primary Carc Selting: The South Warwickshire Experience. BJOG. 2005; 112: 1117-1120.

33. Buckshee $\mathrm{K}$ and Bhatla H. Uterine Balloon Therapy 10 Treat Mcnorhagia. Int J Gynecol Obstet. 1998; 63: 139-143.

34. Leung PL, Tam WH and Yuen PM. Hysteroscopic Appcarance of the Endometrial Cavity Following Thermal Balloon Endmetrial Ablation Fertility an Stcrility. 2003; 79(5): 1226-1228.

35. Morgan $H$ and Advincula AP. Global endomelrial ablation: a modem day solution to an age-old problem. Int J Gynaccol Obstet, 2006; 94(2): 156-166.

36. Meyer WR, Walsh BW, Grainger DA, Peacock LM, Loffer FD and Steege JF. Thermal Blloon And Rollerball Ablation To treat Menorrhagia: A Multicentre Comparison. Obstel Gynecol. 1989; 92: 98-103.

37. Gervaise A, Fernandez H, capella-Allouc $S$, Taylor $S$, vieille SLA and Hamou J. Thermal Balloon Ablation Versus Endometrial Resection for the Treatment of Abnormal Uterine Bleeding: Hyman Reproduction, Vol. 1999; 14(11), 2743-2747. 